\title{
ANALISIS FAKTOR-FAKTOR YANG MEMPENGARUHI PRODUKSI GULA KELAPA DI DESA KARYA TUNAS JAYA KECAMATAN TEMPULING KABUPATEN INDRAGIRI HILIR
}

\author{
PUJI \\ Mahasiswa Program Studi Agribisnis Fakultas Pertanian UNISI \\ Email :Puji@gmail.com
}

\begin{abstract}
ABSTRAK
Di Desa Karya Tunas Jaya banyak tumbuh dan berkembang tanaman kelapa yang dibudidayakan oleh masayarakat sekitar untuk pembuatan gula kelapa yang berskala rumah tangga, produksi gula kelapa di Desa Karya Tunas Jaya mencapai 2,1 Ton/hari. Oleh karena itu, perlu dilakukan analisis faktor-faktor yang mempengaruhi produksi gula kelapa di Desa Karya Tunas Jaya Kecamatan Tempuling Kabupaten Indragiri Hilir. Metode yang digunakan adalah analisis regresi linear berganda, pengumpulan data dilakukan dengan wawancara. Pengambilan sampel dilakukan dengan menggunakan menggunakan metode simple random sampling. Tujuan penelitian ini adalah : (1) Untuk mengetahui faktor faktor yang mempengaruhi produksi gula kelapa di Desa Karya Tunas Jaya Kecamatan Tempuling Kabupaten Indragiri Hilir, (2) Untuk mengetahui pengaruh faktor tersebut terhadap produksi gula kelapa di Desa Karya Tunas Jaya Kecamatan Tempuling Kabupaten Indragiri Hilir. Hasil penelitian menunjukkan bahwa : (1) variabel yang berpengaruh signifikan terhadap produksi gula kelapa di Desa Karya Tunas Jaya Kecamatan Tempuling Kabupaten Indragiri Hilir adalah jumlah nira kelapa $(\alpha=1 \%)$, jumlah pohon $(\alpha=1 \%)$, bahan bakar ( $\alpha=15 \%)$, biaya bahan penolong $(\alpha=15 \%)$, dan umur tanaman $(\alpha=15 \%)$, Sedangkan variabel yang tidak signifikan yaitu tenaga kerja $(\alpha=55 \%)$ dan lama usaha $(\alpha=85 \%)$. (2) besarnya pengaruh masing-masing variabel ditunjukkan oleh koefesien regresi dengan nilai jumlah nira kelapa 0.054 , jumlah pohon kelapa 0.105 , bahan bakar 0.00016 , biaya bahan penolong 0.00015 dan umur tanaman sebesar 0.159
\end{abstract}

Kata Kunci : Gula Kelapa, Nira, Regresi Linear Berganda

\section{PENDAHULUAN}

Salah satu sentra produksi kelapa di Provinsi Riau adalah Kabupaten Indragiri Hilir. Kabupaten Indragiri Hilir merupakan sentra produksi kelapa terbesar $(85,49 \%)$ dengan produksi 471.519ton dan luas perkebunan kelapa 541,388ha (BPSProvinsiRiau, 2010). Perkebunan ini masih didominasi oleh perkebunan kelapa rakyat. Agroindustri gula kelapa di Kabupaten Indragiri Hilir 
merupakan salah satu bidang usaha yang banyak dijadikan mata pencaharian oleh sebagian besar masyarakat terutama di Kecamatan Tempuling yang merupakan penghasil gula kelapa terbesar.

Gula kelapa adalah gula yang dihasilkan dari penguapan nira pohon kelapa (Cocos nucifera Linn). Gula kelapa atau dalam perdagangan dikenal sebagai "gula Jawa" atau "gula merah" biasanya dijual dalam bentuk setengah mangkuk atau setengah elips. Bentuk demikian ini dihasilkan dari cetakan yang digunakan berupa setengah tempurung kelapa (Jawa : bathok). (Santoso, 1993).

Gula kelapa juga merupakan komoditas yang memiliki prospek yang bagus, karena permintaan yang tinggi dari dalam maupun luar negeri. Pada tahun 2009 saja permintaan gula kelapa di Riau adalah sebesar 30 ribu ton sedangkan perbulannya kebutuhan gula kelapa di Riau sekitar 5.000 ton sampai dengan 6.000 ton/ bulan (Disperindag Provinsi Riau 2009).

Di Desa Karya Tunas Jaya ini banyak tumbuh dan berkembang tanaman kelapa yang dibudidayakan oleh masayarakat sekitar untuk pembuatan gula kelapa. Produksi gula kelapa di Desa Karya Tunas Jaya mencapai 2,1 Ton/hari. Industri gula kelapa yang berada di Desa Karya Tunas Jaya telah ada secara turun temurun dan masih bersifat tradisional baik dalam proses produksi ataupun pemasarannya. (Kantor Desa Karya Tunas Jaya, 2017).

Industri gula kelapa di Desa Karya Tunas Jaya merupakan industri yang berskala rumah tangga, dimana penggunaan tenaga kerjanya adalah tenaga kerja dalam keluarga dengan jumlah tenaga kerja kurang dari lima orang. Desa ini merupakan termasuk kedalam daerah penghasil gula kelapa yang telah mendapatkan penyuluhan langsung oleh Dinas koperasi Usaha Mikro Kecil dan Menengah (UMKM) Kabupaten Indragiri Hilir tahun 2016. Dengan adanya penyuluhan ini diharapkan produksi gula kelapa di Desa Karya Tunas Jaya semakin meningkat.

Beberapa hal yang menjadi perhatian dalam industri gula kelapa di Desa Karya Tunas Jaya antara lain umur pohon kelapa yang sudah tua membuat petani lebih sulit menyadap nira nya dibandingkan umur pohon kelapa yang masih muda selain karena pohon yang semakin tinggi umur pohon kelapa yang lebih muda lebih banyak menghasilkan nira dibandingkan yang lebih tua. Tujuan penelitian adalah untuk mengetahui pengaruh faktor tersebut terhadap produksi gula kelapa di Desa Karya Tunas Jaya Kecamatan Tempuling Kabupaten Indragiri Hilir.

\section{TINJAUAN PUSTAKA}

\subsection{Kelapa}

Kelapa (Cocos nucifera) adalah anggota tunggal dalam marga Cocos dari suku aren-arenan atau Arecaceae. Tumbuhan ini dimanfaatkan hampir semua bagiannya oleh manusia sehingga dianggap sebagai tumbuhan serbaguna, terutama bagi masyarakat pesisir. 
Tanaman kelapa mempunyai nilai ekonomi tinggi dan tumbuh baik di daerah tropis dengan suhu sekitar 27 ${ }^{\circ} \mathrm{C}$ dan dapat dijumpai baik di dataran rendah maupun dataran tinggi. Pohon kelapa ini dapat tumbuh dan berbuah dengan baik di daerah dataran rendah dengan ketinggian $0-450 \mathrm{~m}$ dari permukaan laut. Pada dataran tinggi dengan ketinggian antara 450 - $1000 \mathrm{~m}$ dari permukaan laut, walaupun pohon ini dapat tumbuh, waktu berbuahnya lebih lambat, produksinya lebih sedikit dan kadar minyaknya rendah (Amin dan Sarmidi, 2009).

\subsection{Gula Kelapa}

Gula kelapa atau gula merah terbuat dari air sadapan bunga pohon kelapa atau air nira kelapa, sering juga disebut dengan gula jawa. Teksturnya berupa bongkahan berbentuk silinder dan berwarna coklat. Biasanya digunakan dalam bahan pemanis makanan dan minuman dengan cara diiris tipis.

Gula Kelapa ini dibuat dengan menyaring atau mendidihkan getah Nira dari pohon kelapa sampai kandungan air nya menguap habis. Hampir sama dengan apa yang kita kenal Gula Aren. Proses pemanasan dan pengadukan sampai mengental..

Selain itu, kandungan serat Inulin pada Gula Kelapa juga menjelaskan dengan baik keunggulan produk pemanis ini dibandingkan dengan jenis pemanis lain.

\subsection{Faktor Produksi Gula Kelapa}

Faktor produksi adalah semua korbanan yang diberikan pada tanaman agar tanaman tersebut mampu tumbuh dan menghasilkan dengan baik. Faktor produksi sangat menentukan besar kecilnya produksi yang diperoleh.

Beberapa faktor produksi yang terpenting dalam proses produksi adalah lahan, modal (untuk membeli bibit, pupuk, obat-obatan), tenaga kerja dan aspek manajemen (Soekartawi, 2013).

Beberapa daerah sudah memiliki sistem yang bagus dalam menangani sumber daya alam yang satu ini. Menjadikan Kelapa sebagai bahan baku produksi Gula Kelapa dan menjadikanya sebagai komoditas yang bernilai tinggi sampai dapat melakukan perdagangan export permintaan dari luar negeri.

\subsubsection{Nira Kelapa}

Menurut Dyanti (2002), nira merupakan cairan manis mengandung gula pada konsentrasi $7,5 \%$ sampai $20,0 \%$ yang terdapat di dalam bunga tanaman aren, kelapa dan lontar yang pucuknya belum membuka dan diperoleh dengan cara penyadapan. Hasil nira yang diperoleh dipengaruhi oleh beberapa faktor yaitu keadaan iklim mempengaruhi banyaknya nira,dan penyadapan yang dilakukan dalam musim hujan akan menghasilkan nira yang lebih banyak daripada musim kemarau.

\subsubsection{Jumlah Pohon}

Jumlah pohon kelapa sangat menentukan dalam produksi gula kelapa karena semakin banyak pohon yang disadap maka semakin banyak pula jumlah nira yang didapat untuk membuat gula kelapa. Jumlah pohon dapat di tentukan dengan luas lahan yang dimiliki pertani gula kelapa. Lahan sebagai salah satu faktor produksi yang merupakan pabriknya hasil pertanian yang mempunyai 
kontribusi yang cukup besar usahatani. Besar kecilnya produksi dari usaha tani antara lain dipengaruhi oleh luas sempitnya lahan yang digunakan.

\subsubsection{Tenaga Kerja}

Tenaga kerja merupakan salah satu faktor produksi yang memegang peran penting didalam kegiatan usaha tani. Tenaga kerja dapat juga berupa sebagai pemilik (pertanian tradisional) maupun sebagai buruh biasa (pertanian komersial). Ada beberapa hal yang perlu diperhatikan dalam faktor produksi tenagakerja yaitu (Soekartawi, 2002) : (1). Tersedianya tenaga kerja (2.) Kualitas tenaga kerja (3). Jenis kelamin (4). Tenaga kerja musiman (5.) Upah tenaga kerja

\subsubsection{Bahan Bakar}

Ketersedian bahan bakar merupakan hal yang penting untuk mendukung keberlanjutan proses produksi bagi industri pengrajin gula kelapa dan bahan bakar yang sering digunakan dalam proses produksi adalah kayu bakar. Kayu merupakan sumber energi yang pertama dikenal dan digunakan manusia secara universal. Selain untuk memasak, kayu juga digunakan untuk pemanasan di daerah beriklim dingin.

\subsubsection{Pengalaman Berusaha}

Pengalaman kerja adalah pengetahuan atau keterampilan yang telah diketahui dan dikuasai seseorang yang akibat dari perbuatan atau pekerjaan yang telah dilakukan selama beberapa waktu tertentu (Trijoko, 1980).

\subsubsection{Biaya Bahan Penolong}

Biaya bahan penolong termasuk kedalam modal petani gula untuk memproduksi gula kelapa. Pengertian Modal Usaha menurut Kamus Besar Bahasa Indonesia dalam Listyawan Ardi Nugraha (2011) "modal usaha adalah uang yang dipakai sebagai pokok (induk) untuk berdagang, melepas uang, dan sebagainya; harta benda (uang, barang, dan sebagainya) yang dapat dipergunakan untuk menghasilkan sesuatu yang menambah kekayaan". Modal dalam pengertian ini dapat diinterpretasikan sebagai sejumlah uang yang digunakan dalam menjalankan kegiatan-kegiatan bisnis.

\subsubsection{Umur Pohon Kelapa}

Kelapa mulai dapat disadap umur 6-8 tahun serta lamanya dapat disadap 25-30 tahun, pengambilan nira dengan cara memotong tangkai bunganya. Penyadapan dilakukan sepanjang tahun selama 4 bulan, hasil niranya $2 \mathrm{~kg}$ per hari sadap. Rendemen nira menjadi gula merah yaitu $12-18 \%$, gula merah yang dihasilkan antara 30 $40 \mathrm{~kg}$ per pohon per tahun. Umur pohon kelapa juga menentukan nira yang dihasilkan, pohon yang lebih muda akan menghasilkan nira lebih banyak daripada pohon yang lebih tua

\section{METODOLOGI PENELITIAN}

\subsection{Waktu dan Tempat Penelitian}

Penelitian ini dilakukan di Desa Karya Tunas Jaya Kecamatan Tempuling Kabupaten Indragiri Hilir. Lokasi penelitian diambil secara purposive (sengaja) dengan pertimbangan bahwa Desa Karya Tunas Jaya merupakan salah satu sentra pembuatan gula kelapa. 
Penelitian ini dilaksanakan selama tiga bulan, yaitu pada bulan Februari sampai April 2017.

\subsection{Metode Pengumpulan Data}

Teknik pengambilan data dalam penelitian ini yaitu dengan cara

1. Wawancara yaitu pengumpulan data dengan melakukan wanwancara secara langsung dan terstruktur dengan mengajukan pertanyaan kepada para responden dengan menggunakan kuisioner

2. Observasi yaitu dengan melakukan pengamatan langsung, catatan sistematis didaerah penelitian.

\subsection{Jenis dan Sumber Data}

\subsubsection{Data Primer}

Menurut Umar (2003), data primer merupakan data yang diperoleh langsung di lapangan oleh peneliti sebagai obyek penulisan. Dalam hal ini penulis melakukan wawancara langsung terhadap responden dengan menggunakan kuisioneryang meliputi identitas responden, faktor-faktor produksi yang digunakan ( nira kelapa, luas lahan, tenaga kerja, kayu bakar, pengalaman berusaha, modal dan umur kelapa) dan lain-lain.

\subsubsection{Data Sekunder}

Menurut Sugiyono (2005), data sekunder adalah data yang tidak langsung memberikan data kepada peneliti, misalnya penelitian harus melalui orang lain atau mencari melalui dokumen.

\subsection{Metode Pengambilan Sampel}

Menurut Arikunto (2008:116) "Penentuan pengambilan Sample sebagai berikut:Apabila kurang dari 100 lebih baik diambil semua hingga penelitiannya merupakan penelitian populasi. Jika jumlah subjeknya besar dapat diambil antara $10-15 \%$ atau 20$55 \%$ atau lebih tergantung sedikit banyaknya dari: 1). Kemampuan peneliti dilihat dari waktu, tenaga dan dana 2). Sempit luasnya wilayah pengamatan dari setiap subyek, karena hal ini menyangkut banyak sedikitnya dana.

3).Besar kecilnya resiko yang ditanggung oleh peneliti untuk peneliti yang resikonya besar, tentu saja jika samplenya besar hasilnya akan lebih baik.

Populasi pengrajin gula kelapa yang berproduksi di Desa Karya Tunas Jaya adalah sebanyak 143 orang, dari jumlah populasi pengrajin gula kelapa di ambil sebanyak 30\% sehingga diperoleh sampel 43 pengrajin gula kelapa dengan menggunakan metodesimple random sampling. Menurut Sugiyono (2001) dinyatakan simple (sederhana) karena pengambilan sampel anggota populasi dilakukan secara acak tanpa memperhatikan strata yang ada dalam populasi itu.

\subsection{Metode Analisis Data}

\subsubsection{Analisis Regresi Linear Berganda}

Dalam penelitian ini analisis data yang digunakan adalah analisis regresi linear berganda. Analisis ini digunakan untuk mengetahui pengaruh variabel bebas dengan variabel terikat. Menurut Sofjan (1984) dengan rumus : 


\author{
$\mathrm{Y}=\mathrm{a}+\mathrm{b}_{1} \mathrm{X}_{1}+\mathrm{b}_{2} \mathrm{X}_{2}+\mathrm{b}_{3} \mathrm{X}_{3}+\mathrm{b}_{4} \mathrm{X}_{4}$ \\ $+\mathrm{b}_{5} \mathrm{X}_{5}+\mathrm{b}_{6} \mathrm{X}_{6}+\mathrm{b}_{7} \mathrm{X}_{7}+\ldots \ldots \mathrm{e}$ \\ Keterangan : \\ Y : Produksi Gula Kelapa (Kg) \\ a : Konstanta \\ $\mathrm{b}:$ Koefisien \\ $\mathrm{X}_{1}$ : Nira Kelapa (Liter) \\ $\mathrm{X}_{2}$ : Jumlah Pohon (Pohon) \\ $\mathrm{X}_{3}$ : Tenaga Kerja (HOK) \\ $\mathrm{X}_{4}$ :Bahan Bakar $(\mathrm{Rp})$ \\ $\mathrm{X}_{5}$ : Pengalaman Berusaha (Tahun) \\ $\mathrm{X}_{6}$ : Biaya Bahan Penolong (Rp) \\ $\mathrm{X}_{7}$ : Umur Kelapa (Tahun) \\ e : Standar Error
}

\subsubsection{Pengujian Model}

Untuk menganalisa lebih lanjut maka perhitungan regresi dilakukan untuk mendapatkan nilai-nilai sebagai berikut :

\section{Koefisien Determinasi $\left(\mathrm{R}^{2}\right)$}

$\mathrm{R}^{2}$ untuk melihat apakah tepat penggunaan persamaan regresi dari analisa atau model, maka perlu di lakukan pengetesan, pengetesan yang perlu di lakukan adalah untuk mengetahui apakah benar waktu yang menentukan variabel yang di ramalkan.

\section{Uji T}

Uji ini digunakan untuk mengetahui apakah masing-masing variabel independen secara sendirisendiri mempunyai pengaruh secara signifikan terhadap variabel dependen.
Uji t pada dasarnya menunjukan seberapa jauh pengaruh satu variabel independen secara individual menerangkan variasi variabel terikat (Ghozali, 2006).

\section{Uji F}

Uji $F$ digunakan untuk menunjukkan apakah keseluruhan variabel independen berpengaruh terhadap variabel dependen. Kriteria pengujiannya apabila nilai F-hitung < F-tabel artinya seluruh variabel independen yang digunakan tidak berpengaruh secara signifikan terhadap variabel dependen. Apabila Fhitung > Ftabel berartiseluruh variabel independen berpengaruh secara signifikan terhadap variabel dependen dengan taraf signifikan tertentu.(Ghozali ,2011)

\subsubsection{Uji Asumsi Klasik} 1. Uji Multikolineritas

Menurut rasidin dan bonar (2006) Multikolineritas adalah sutu hubungan linear atau lebih variabel independen (predicator variabels). Dalam hal ini variabel - variabel bebas yang bersifat orthogonal adalah variabel bebas (independent) yang bernilai korelasi diantara sama dengan nol. Jika terdapat korelasi yang sempurna diantara sesama variabel independen, dengan kata lain koefesien korelasi sama dengan satu maka (a) koefesien paremeter menjadi tidak dapat di tafsir, dan (b) nilai standard error setiap koefesien estimasi menjadi tidak terhingga.

Untuk mengetahui ada tidaknya multikolneritas di dalam 
sebuah model data di indetifiksi dari ciri - ciri sebagai berikut:

1. Nilai R-square signifikan, uji F signifikan, tetapi standar eror dan tingkat signifikansi masingmasing varibel rendah.

2. Multikolineritas dapat diperiksa menggunakan Variance Infalation factor(VIF) untuk masing masing variabel independen mempunyai nilai VIF $>10$ berati telah terjadi Multikolineritas. Beberapa juga ahli berpendapat bawa nilai tolerasnsi kurang dari 1 atau VIF lebih besar dari 10 menunjukkan multikolineritas signifikan. (Ghozali ,2011). Halhal yang perlu dilakukan bila terjadi multikolinearitas adalah :

a. Transpormasi data (misalnya dengan logaritma natural)

b. Mengeluarkan variabel yang berkorelasi dalam model

c. Mencari data tambahan

\section{Uji Heterokedastisitas}

Uji Heterokedastisitas bertujuan menguji apakah dalam model regresi terjadi ketidaksamaan variance dari satu residual satu pengamatan ke pengamatan yang lain.. Jika nilai signifikan anatara variabel independen dengan absolut residual lebih dari 0.05 maka tidak terjadi masalah Heterokedastisitas . (Ghozali, 2011)..

\section{Uji Autokorelasi}

Uji autokorelasi bertujuan menguji apakah dalam model regresi linear ada korelasi antara kesalahan pengganggu pada periode $\mathrm{t}$ dengan kesalahan pengganggu pada periode $\mathrm{t}$ 1 (sebelumnya). Jika terjadi korelasi, maka dinamakan ada problem autokorelasi (Imam Ghozali, 2005). Model regresi yang baik adalah regresi yang bebas dari autokorelasi dapat dilakukan melalui pengujian terhadap nilai uji Durbin Watshon(uji DW) dengan ketentuan sebagai berikut :

Ada Autokorelasi : 0-1.224

Daerah Keragu-raguan : 1.224-1.553

Tidak Ada Autokorelasi : 1.553-2.447

Daerah Keragu-raguan : 2.447-2.776

Ada Autokorelasi : 2.776-4

\section{HASIL DAN PEMBAHASAN}

\subsection{Proses Pengolahan Gula Kelapa di Desa Karya Tunas Jaya}

Proses pengolahan gula dapat di golongkan menjadi dua yaitu proses penyadapan nira dari tandan bunga atau mayang kelapa dan pemasakan nira kelapa menjadi gula kelapa.

Proses penyadapan tandan bunga kelapa dilakukan dengan cara yaitu:

- Memilih tandan bunga kelapa untuk disadap lalu dibersihkan dari berbagai sampah dan kotorannya

- $\quad$ Tandan bunga yang dipilih lalu dililit atau diikat dengan tali rafia dengan cara ini tandan bunga kelapa di bekuk atau dibengkokkan agar lebih mudah saat penyadapannya nanti

- Setelah 2-3 hari baru ujung tandan diiris sekitar $\pm 10 \mathrm{~cm}$ dengan pisau/arit deres yang tajam, dalam waktu 3-5 hari nira 
kelapa akan mulai keluar dan biasanya akan ditampung dengan wadah botol air mineral yang besar

- $\quad$ Agar nira kelapa tidak rusak dan asam wadah nira perlu diberi bahan pengawet biasanya para penderes menggunakan bahan pengawet Natrium Metabisulfit dan irisan atau serpihan kayu resak

- $\quad$ Penyadapan dilakuan 2 kali yaitu sebelum pukul 08.00 dan setelah jam 16.00

- $\quad$ Sebelum wadah nira dipasang kembali untuk penderesan berikutnya ujung tandan bunga kelapa diiris sedikit dengan sekali sentuhan untuk memperlancar keluar niranya

Proses pengolahan nira kelapa menjadi gula kelapa dilakukan dengan cara yaitu:

- Nira yang diperoleh biasanya dikumpulkan kedalam wadah yang lebih besar menggunakan jerigen 20-30 liter

- Sebelum nira dimasak harus disaring terlebih dahulu kedalam wajan/panci yang telah disiapkan untuk memasak nira

- Nira dimasak dengan bahan bakar kayu bakar yang diperoleh dari dari kebun kelapa itu sendiri yaitu berupa pelepah-pelepah kelapanya

- $\quad$ Setelah nira setengah masak nira akan diberikan parutan kelapa secukupnya untuk mempercepat pengentalan gula

- $\quad$ Lama pemasakan nira tergantung dari banyak nira dan kadar air nya
- Jika nira telah mengental dan bewarna kemerahan wajan di angkat lalu nira dituangkan kedalam cetakan dan biarkan dingin

- Cetakan yang digunakan adalah cetakan yang terbuat dari bambu

\subsection{Faktor-Faktor Yang di Gunakan Dalam Produksi Gula Kelapa di Desa Karya Tunas Jaya Kecamatan Tempuling}

\subsubsection{Jumlah Nira Kelapa (Liter)}

Nira kelapa dapat diartikan sebagai jumlah nira yang menghasilkan produksi gula kelapa di Desa Karya Tunas Jaya Kecamatan Tempuling. Secara rata-rata jumlah nira kelapa yang digunakan oleh petani gula kelapa di Desa Karya Tunas Jaya yaitu sebanyak 90-375 liter. Untuk lebih jelas dapat dilihat pada tabel 1 .

Tabel 1. Jumlah Nira Kelapa

\begin{tabular}{llll}
\hline No & $\begin{array}{l}\text { Nira } \\
\text { Kelapa } \\
\text { (Liter) }\end{array}$ & $\begin{array}{l}\text { Jumlah } \\
\text { Petani }\end{array}$ & $\begin{array}{l}\text { Persentase } \\
(\%)\end{array}$ \\
\hline $\mathbf{1}$ & $90-140$ & 28.00 & 65.10 \\
$\mathbf{2}$ & $141-190$ & 7.00 & 16.30 \\
$\mathbf{3}$ & $191-240$ & 8.00 & 18.60 \\
\hline Jumlah & 43.00 & 100.00 \\
\hline Sumber : Data primer diolah 2017 \\
Berdasarkan tabel 1 diatas \\
dapat dilihat bahwa jumlah nira kelapa \\
yang terbanyak adalah 90-140 liter \\
dengan jumlah petani 28 orang \\
(65.1\%), 141-190 liter sebanyak 7 \\
orang petani (16.3\%), dan 191-240 \\
liter dengan jumlah petani 8 orang \\
(18.6\%).Untuk menghasilkan 1 kg \\
gula kelapa petani gula kelapa harus
\end{tabular}


membutuhkan nira kelapa sekitar atau sebanyak 6-7 liter nira.

\subsubsection{Jumlah Pohon Yang di Sadap (Batang)}

Jumlah pohon yang disadap merupakan pohon kelapa yang diambil atau disadap niranya untuk memproduksi gula kelapa jumlah pohon yang disadap dalam penelitian ini di Desa Karya Tunas Jaya Kecamatan Tempuling adalah 40-100 pohon kelapa.Untuk lebih jelasnya dapat dilihat pada tabel 2 .

Tabel 2. Jumlah Pohon Kelapa yang di Sadap

\begin{tabular}{llll}
\hline No & $\begin{array}{l}\text { Jumlah } \\
\text { Pohon }\end{array}$ & $\begin{array}{l}\text { Jumlah } \\
\text { Petani }\end{array}$ & $\begin{array}{l}\text { Persentase } \\
(\%)\end{array}$ \\
\hline $\mathbf{1}$ & $40-70$ & 26.00 & 60.50 \\
$\mathbf{2}$ & $71-100$ & 17.00 & 39.50 \\
\hline Jumlah & 43.00 & 100.00 \\
\hline \multicolumn{2}{l}{ Sumber : Data primer diolah 2017}
\end{tabular}

Dari tabel 2 dapat dilihat bahwa jumlah petani yang menyadap pohon kelapa terbanyak yaitu 40-70 pohon dengan jumlah petani 26 orang $(60.50 \%)$, sedangkan jumlah petani paling sedikit menyadap pohon kelapanya yaitu 71-100 pohon dengan jumlah petani 17 orang (39.50\%). Petani menyadap pohon kelapa menggunakan sistem acak yang lebih mudah disadap, dimana petani tidak menyadap pohon kelapa yang terlalu tinggi atau yang lebih tua.

\subsubsection{Tenaga Kerja (HOK)}

Tenaga kerja merupakan faktor produksi yang penting dan perlu diperhitungkan dalam proses produksi dalam jumlah cukup, bukan saja terlihat dari tersedianya tenaga kerja, tetapi juga kualitas dan macam tenaga kerja perlu diperhatikan. Di Desa Karya Tunas Jaya hanya menggunakan tenaga kerja dalam keluarga untuk memproduksi gula kelapa. Dalam memproduksi gula kelapa hanya dibutuhkan 2 orang tenaga kerja saja, yaitu 1 orang tenaga kerja pria dan 1 orang tenaga kerja wanita karena usaha gula kelapa merupakan usaha keluarga. 1 orang tenaga kerja pria digunakan untuk menyadap nira kelapa , sedangkan 1 orang tenaga kerja wanita digunakan untuk proses pengolahan gula kelapa.

\subsubsection{Penggunaan Bahan Bakar (Rp)}

Bahan bakar merupakan bahan yang digunakan petani dalam memproduksi gula kelapa. Bahan bakar sangat penting dalam proses produksi gula kelapa karena tanpa adanya bahan bakar maka produksi gula kelapa tidak akan terjadi penggunaan bahan bakar dalam produksi gula kelapa adalah Rp.10.000-30.000. Di Desa Karya Tunas Jaya bahan bakar yang digunakan petani untuk memproduksi gula kelapa berupa kayu yang dibeli petani dalam jumlah kubik, dan ada juga yang menggunakan pelepah kelapa sebagai bahan bakar. Untuk lebih jelasnya jumlah penggunaan bahan bakar dalam memproduksi gula kelapa di Desa Karya Tunas Jaya dapat dilihat pada tabel 3 .

Tabel 3. Bahan Bakar

\begin{tabular}{llll}
\hline No & $\begin{array}{l}\text { Bahan } \\
\text { Bakar } \\
\text { (Rp) }\end{array}$ & $\begin{array}{l}\text { Jumlah } \\
\text { Petani }\end{array}$ & $\begin{array}{l}\text { Persentase } \\
(\%)\end{array}$ \\
\hline $\mathbf{1}$ & $10.000-$ & 35.00 & 81.40 \\
\hline
\end{tabular}




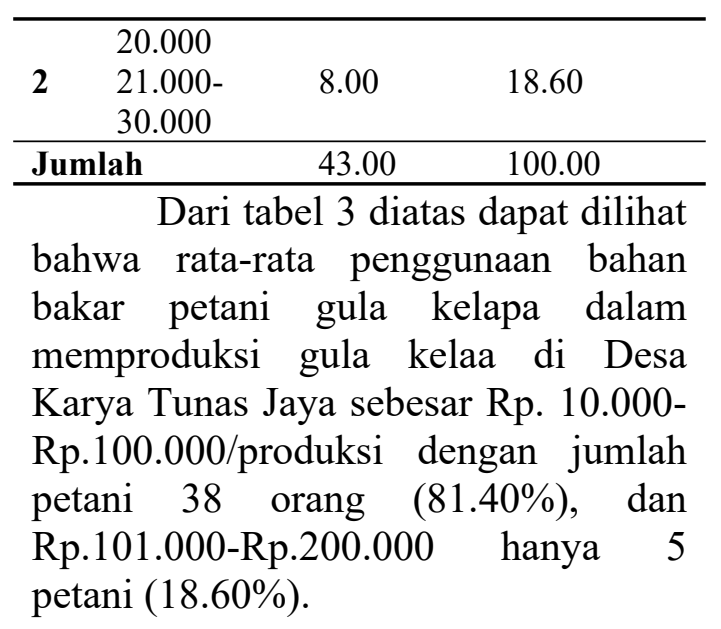

\subsubsection{Pengalaman Usaha (Tahun)}

Pengalaman berusaha merupakan salah satu faktor lain yang mendukung keberhasilan usaha gula kelapa. Pengalaman berusaha sangat menentukan keterampilan seorang pengrajin dalam berusaha di usaha gula kelapa. Seorang yang memiliki banyak pengalaman usaha, keterampilannya cukup tinggi sehingga usaha akan lebih baik. Sebaliknya jika kurang berpengalaman maka produk yang dihasilkan kurang berkualitas dan tidak maksimal.Pengalaman usaha petani gula kelapa dalam memproduksi gula kelapa di Desa Karya Tunas Jaya di sajikan dalam tabel 4.

Tabel 4. Pengalaman Usaha

\begin{tabular}{llll}
\hline No & $\begin{array}{l}\text { Lama } \\
\text { Usaha } \\
\text { (Tahun) }\end{array}$ & $\begin{array}{l}\text { Jumlah } \\
\text { Petani }\end{array}$ & $\begin{array}{l}\text { Persentase } \\
(\%)\end{array}$ \\
\hline $\mathbf{1}$ & $2-7$ & 24.00 & 55.80 \\
$\mathbf{2}$ & $8-12$ & 13.00 & 30.20 \\
$\mathbf{3}$ & $13-17$ & 6.00 & 14.00 \\
\hline Jumlah & 43.00 & 100.00 \\
\hline
\end{tabular}

Sumber : Data primer diolah 2017

Lama usaha petani dalam memproduksi gula kelapa dari tabel 4 dapat dilihat bahwa pengalaman usaha terbanyak yaitu 2-7 tahun dengan jumlah 24 petani (55.80\%), pengalaman usaha 8-12 tahun dengan jumlah petani 13 orang $(30.20 \%)$ sedangkan paling sedikit 13-17 tahun dengan jumlah petani 6 orang $(14.00 \%)$.

\subsubsection{Biaya Bahan Penolong (Rp)}

Biaya bahan penolong merupakan salah satu faktor produksi yang sangat penting. Tanpa adanya biaya bahan penolong produksi tidak akan terjadi. Petani gula kelapa di Desa Karya Tunas Jaya dalam memproduksi gula kelapa mengeluarkan biaya bahan penolong berupa resak dan obat gula untuk pengawet (natrium metabisulfit). Jumlah biaya bahan penolong yang dikeluarkan dapat dilihat pada tabel 5 .

Tabel 5. Biaya Bahan Penolong

\begin{tabular}{llll}
\hline No & $\begin{array}{l}\text { Biaya } \\
\text { Bahan } \\
\text { Penolong } \\
\text { (Rp) }\end{array}$ & $\begin{array}{l}\text { Jumlah } \\
\text { Petani }\end{array}$ & $\begin{array}{l}\text { Persentase } \\
(\%)\end{array}$ \\
\hline $\mathbf{1}$ & $10.000-$ & 35.00 & 81.40 \\
& 22.500 & & \\
$\mathbf{2}$ & $22.600-$ & 8.00 & 18.60 \\
& 35.000 \\
\hline Jumlah & 43.00 & 100.00 \\
\hline Sumber : Data primer diolah 2017 \\
\multicolumn{4}{c}{ Dari tabel 5 diatas dapat dilihat } \\
bahwa petani banyak mengeluarkan \\
biaya bahan penolong sebesar \\
Rp.10.000-Rp.22.500 dengan jumlah \\
petani 35 orang (81.40\%) sedangkan \\
petani yang mengeluarkan biaya bahan \\
penolong sebesar Rp.22.600- \\
Rp.35.000 hanya sebanyak 8 orang \\
(18.60\%).
\end{tabular}




\subsubsection{Umur Pohon Kelapa (Tahun)}

Umur pohon kelapa menjadi salah satu faktor produksi karena pohon kelapa yang petani sadap berpengaruh terhadap hasil produksi gula kelapa di Desa Karya Tunas Jaya Kecamatan Tempuling.

Umur tanaman yang lebih muda lebih banyak menghasilkan nira akan tetapi kualitas gula kelapanya tidak lebih baik dibandingkan dengan gula yang dihasilkan nira umur kelapa yang sudah tua karena umur kelapa yang lebih tua nira yang dihasilkan lebih kental dari yang lebih muda. Umur kelapa yang disadap untuk dijadikan gula kelapa di Desa Karya Tunas Jaya dapat dilihat pada tabel 6 .

Tabel 6. Umur Pohon Kelapa

\begin{tabular}{llll}
\hline No & $\begin{array}{l}\text { Umur } \\
\text { Pohon } \\
\text { (Tahun) }\end{array}$ & $\begin{array}{l}\text { Jumlah } \\
\text { Petani }\end{array}$ & $\begin{array}{l}\text { Persentase } \\
(\%)\end{array}$ \\
\hline $\mathbf{1}$ & $5-10$ & 25.00 & 58.10 \\
$\mathbf{2}$ & $11-15$ & 13.00 & 30.30 \\
$\mathbf{3}$ & $16-20$ & 5.00 & 11.60 \\
\hline Jumlah & 43.00 & 100.00 \\
\hline
\end{tabular}

Sumber : Data primer diolah 2017

Berdasarkan tabel 6 dapat dilihat bahwa rata-rata umur pohon kelapa yang disadap para petani yaitu yang berumur 5-10 tahun sebanyak 25 orang petani $(58.10 \%)$ sedangkan yang berumur 11-15 tahun sebanyak 13 petani $(30.30 \%)$ dan yang paling sedikit yaitu berumur 16-20 tahun sebanyak 5 orang petani $(11.60 \%)$.

\subsection{Hasil Analisis Data}

\subsubsection{Regresi Linear Berganda}

Hasil analisis penelitian ini menggunakan program SPSS 24 dengan persamaan regresi linear berganda yang dapat dilihat pada tabel 7 berikut :

Tabel 7. Hasil Analisis Regresi

\begin{tabular}{lllll}
\hline No & Variabel & $\begin{array}{l}\text { Koefisien } \\
\text { Regresi }\end{array}$ & $\begin{array}{l}\text { t- } \\
\text { Hitung }\end{array}$ & Sig \\
\hline $\mathbf{1}$ & Intercept & -2.019 & -.971 & .338 \\
$\mathbf{2}$ & Nira Kelapa $\left(\mathrm{X}_{1}\right)$ & .054 & 2.745 & $.009^{(\mathrm{a})}$ \\
$\mathbf{3}$ & Jumlah Pohon $\left(\mathrm{X}_{2}\right)$ & .105 & 2.839 & $.007^{(\mathrm{a})}$ \\
$\mathbf{4}$ & Tenaga Kerja $\left(\mathrm{X}_{3}\right)$ & 1.483 & .607 & .548 \\
$\mathbf{5}$ & Bahan Bakar $\left(\mathrm{X}_{4}\right)$ & .00016 & 1.534 & $.134^{(\mathrm{b})}$ \\
$\mathbf{6}$ & Lama Usaha $\left(\mathrm{X}_{5}\right)$ & -.018 & -.196 & .846 \\
$\mathbf{7}$ & Biaya Bahan Penolong $\left(\mathrm{X}_{6}\right)$ & .00015 & 1.634 & $.111^{\text {(b) }}$ \\
$\mathbf{8}$ & Umur Tanaman $\left(\mathrm{X}_{7}\right)$ & .159 & 1.563 & $.127^{(\mathrm{b})}$ \\
\hline
\end{tabular}

Sumber : Data primer diolah 2017

$\mathrm{R}^{2}: 0.89$

F tabel : 2.29

F hitung : 42.028

Ket : a: Signifikan pada taraf $\alpha 1 \%$

b. Signifikan pada taraf $\alpha 15 \%$

Berdasarkan tabel 7 maka persamaan regresi linear berganda adalah :

\subsubsection{Pengujian Model}

\section{Koefisien Determinasi $\left(\mathbf{R}^{2}\right)$}

Variasi pengaruh variabel bebas terhadap variabel tidak bebas ditunjukkan oleh koefisien determinasi. Nilai koefisien determinasi $\mathrm{r}^{2}$ adalah sebesar 0.89, yang artinya $89 \%$ variasi naik turunnya produksi gula kelapa dipengaruhi oleh faktor nira kelapa, jumlah pohon, tenaga kerja, bahan 
bakar, lama usaha, modal dan umur tanaman kelapa, sedangkan sisanya $11 \%$ dipengaruhi oleh faktor lain yang tidak dimasukkan dalam model regresi.

\section{Uji F}

Uji F dilakukan untuk melihat pengaruh variabel independent ( secara bersama-sama) terhadap variabel dependet secara statistik. Hal ini disimpulkan berdasarkan nilai $\mathrm{F}$ hitung sebesar 42.028, sedangkan nilai $\mathrm{F}$ tabel (0.05) adalah sebesar 2.28. Dalam pengambilan keputusan diketahui bahwa apabila F-hitung $>$ Ftabel berarti seluruh variabel independen berpengaruh secara signifikan terhadap variabe lndependen. Ini berarti bahwa nira kelapa, jumlah pohon, tenaga kerja, bahan bakar,lama usaha, modal dan umur tanaman berpengaruh secara simultan terhadap produksi gula kelapa di Desa Karya Tunas Jaya Kecamatan Tempuling.

\section{Uji t}

Dari tabel 7 variabel yang signifikan adalah variabel jumlah nira kelapa $(\alpha=1 \%)$, jumlah pohon $(\alpha=1 \%)$, bahan bakar $(\alpha=15 \%)$, biaya bahan penolong $(\alpha=15 \%)$,umur tanaman $(\alpha=15 \%)$, sedangkan variabel yang tidak signifikan yaitu tenaga kerja $(\alpha=55 \%)$ dan lama usaha $(\alpha=85 \%)$.

a. Pada variabel nira kelapa nilai thitung 2.745lebih besar dari nilai ttabel2.030, artinya variabel nira kelapa signifikan pada taraf kepercayaan 99\% $(\alpha=1 \%)$

b. Variabel jumlah pohon kelapa nilai t-hitung 2.839lebih besar dari nilai t-tabel2.030, artinya variabel jumlah pohon kelapa signifikan pada taraf kepercayaan 99\% $(\alpha=1 \%)$

c. Variabel bahan bakar nilai thitung 1.534lebih besar dari nilai ttabel 1.306 , artinya variabel bahan bakar signifikan pada taraf kepercayaan $85 \%(\alpha=15 \%)$

d. Variabel biaya bahan penolong nilai t-hitung 1.634lebih besar dari nilai t-tabel1.471, artinya variabel nira kelapa signifikan pada taraf kepercayaan $85 \%(\alpha=15 \%)$

e. Variabel umur tanaman nilai thitung 1.563lebih besar dari nilai ttabel 1.306 , artinya variabel bahan bakar signifikan pada taraf kepercayaan $85 \%(\alpha=15 \%)$

\subsubsection{Uji Asumsi Klasik}

\section{Uji Multikolinearitas}

Uji Multikolinearitas dapat dilihat pada tabel 8 .

Tabel 8. Uji Multikoleniaritas

\begin{tabular}{lc}
\hline Variabel & Nilai VIF \\
\hline Nira Kelapa $\left(\mathrm{X}_{1}\right)$ & 5.801 \\
Jumlah Pohon $\left(\mathrm{X}_{2}\right)$ & 3.940 \\
Tenaga Kerja $\left(\mathrm{X}_{3}\right)$ & 3.532 \\
Bahan Bakar $\left(\mathrm{X}_{4}\right)$ & 3.359 \\
Lama Usaha $\left(\mathrm{X}_{5}\right)$ & 1.075 \\
Biaya Bahan Penolong & 3.396 \\
$\left(\mathrm{X}_{6}\right)$ & \\
Umur Tanaman $\left(\mathrm{X}_{7}\right)$ & 1.185 \\
\hline \multicolumn{2}{l}{ Sumber : data primer di olah 2017}
\end{tabular}

Berdasarkan tabel 8 dapat dilihat bahwa nilai-nilai VIF variabel nira kelapa $\left(\mathrm{X}_{1}\right)$, Jumlah Pohon $\left(\mathrm{X}_{2}\right)$, Tenaga Kerja $\left(\mathrm{X}_{3}\right)$, Bahan Bakar $\left(\mathrm{X}_{4}\right)$, Lama Usaha $\left(\mathrm{X}_{5}\right)$, Modal $\left(\mathrm{X}_{6}\right)$, Umur Tanaman $\left(\mathrm{X}_{7}\right)$ nilai VIF $<10$, maka tidak terjadi multikolinearitas. 
Multikolineritas dapat diperiksa menggunakan Variance Infalation factor(VIF) untuk masing - masing variabel independen mempunyai nilai VIF $>10$ berati telah terjadi Multikolineritas. Di mana menurut Duwi Priyatno (2009) variabel dikatakan mempunyai masalah multikolinearitas apabila nilai tolerance lebih kecil dari 0,1 atau nilai VIF lebih besar dari 10.

\section{Uji Heterokedastisitas}

Pendektesian ada tidaknya heterokedastisitas bisa dilakukan dengan menggunakan metode glejeser test, yaitu dengan cara meregresikan nilai absolute resisdual terhadap variabel independent. Dapat di lihat pada tabel 9 :

Tabel 9. Uji Heterokedastisitas

\begin{tabular}{lc}
\hline Variabel & Signifikansi \\
\hline Nira Kelapa $\left(\mathrm{X}_{1}\right)$ & .962 \\
Jumlah Pohon $\left(\mathrm{X}_{2}\right)$ & .858 \\
Tenaga Kerja $\left(\mathrm{X}_{3}\right)$ & .107 \\
Bahan Bakar $\left(\mathrm{X}_{4}\right)$ & .772 \\
Lama Usaha $\left(\mathrm{X}_{5}\right)$ & .228 \\
Biaya Bahan & .028 \\
Penolong $\left(\mathrm{X}_{6}\right)$ & \\
Umur Tanaman $\left(\mathrm{X}_{7}\right)$ & .164 \\
\hline
\end{tabular}

Sumber : data primer di olah 2017

Berdasarkan tabel 9 dapat dilihat bahwa analisis dari perhitungan tersebut menunjukkan bahwa variabel nira kelapa, jumlah pohon, tenaga kerja, bahan bakar, lama usaha dan umur tanaman tidakada gangguan heterokedastisitas yang terjadi dalam estimasi parameter model penduga, sedangkan variabel biaya bahan penolong mengalami gangguan heterokedastisitas dimana nilai thitung yang signifikan lebih dari 0.05 jadi secara keseluruhan dapat disimpulkan bahwa tidak ada masalah heterokedastisitas. Menurut Ghozali (2011) jika nilai signifikan anatara variabel independen dengan absolut residual lebih dari 0.05 maka tidak terjadi masalah Heterokedastisitas .

\section{Uji Autokorelasi}

Model regresi yang baik adalah regresi yang bebas dari autokorelasi dapat dilakukan melalui pengujian terhadap nilai uji Durbin-Watshon (uji DW) dengan ketentuan sebagai berikut

Ada Autokorelasi $\quad: 0-1.224$

Daerah Keragu-raguan $\quad: 1.224-1.553$

Tidak Ada Autokorelasi : 1.553-2.447

Daerah Keragu-raguan : 2.447-2.776

Ada Autokorelasi $\quad$ : 2.776-4

Dalam penelitian ini dihasilkan nilai Durbin-Watshon(DW) sebesar 2.224 yang berada pada interval nilai 1.553-2.447 yang berarti tidak ada autokorelasi.

\subsubsection{Pengaruh Faktor-Faktor Produksi Gula Kelapa}

1. Koefisien regresi jumlah nira kelapa sebesar 0.054,artinya apabila variabel nira kelapa bertambah 1 liter maka produksi gula kelapa akan meningkat sebesar 0.054 kg. Hal ini disebabkan karena nira kelapa merupakan bahan utama pembuatan gula kelapasemakain banyak nira yang disadap maka produksi akan semakin meningkat. 
2. Koefisien regresi jumlah pohon kelapa sebesar 0.105, artinya apabila variabel jumlah pohon kelapa bertambah 1 pohon maka produksi gula kelapa akan meningkat sebesar $0.105 \mathrm{~kg}$. Hal ini disebabkan apabila jumlah pohon yang disadap semakin banyak maka semakin banyak pula nira yang didapat dan produksi juga akan semakin meningkat.

3. Koefisien regresi bahan bakar sebesar 0.00016, artinya apabila variabel bahan bakar bertambah Rp. 1000 maka produksi gula kelapa akan meningkat sebesar $0.16 \mathrm{~kg}$. Hal ini dikarenakan bahan bakar merupakan bahan yang sangat penting dalam proses produksi gula kelapa terutama dalam proses pemasakan nira.

4. Koefisien regresi biaya bahan penolong sebesar 0.00015 ,artinya apabila variabel biaya bahan penolongbertambah Rp. 1000 maka produksi gula kelapa akan meningkat sebesar 0.15 kg.biaya bahan penolong merupakan faktor produksi yang sangat penting dalam pembuatan gula kelapa dan bahan penolong dalam penelitian ini termasuk kedalam modal petani.

5. Koefisien regresi umur tanaman sebesar 0.159 , artinya apabila variabelumur tanaman bertambah 1 tahun maka produksi gula kelapa akan meningkat sebesar $0.159 \mathrm{~kg}$.

\section{KESIMPULAN DAN SARAN}

\subsection{Kesimpulan}

Dari hasil penelitian dapat diambil kesimpulan yaitu :
1. Faktor-faktor yang mempengaruhi produksi gula kelapa di Desa Karya Tunas Jaya Kecamatan Tempuling adalah jumlah nira kelapa $(\alpha=1 \%)$, jumlah pohon $(\alpha=1 \%), \quad$ bahan bakar ( $\alpha=15 \%$ ), biaya bahan penolong $(\alpha=15 \%)$, dan umur $\operatorname{tanaman}(\alpha=15 \%)$. Sedangkan variabel yang tidak signifikan yaitutenaga kerja $(\alpha=55 \%)$ dan lama usaha $(\alpha=85 \%)$.

2. Besarnya pengaruh masing-masing variabel adalah sebagai berikut :

a) Variabel nira kelapaberpengaruh positif terhadap produksi gula kelapa dengan koefisien regresi nira kelapa sebesar 0.054, artinya apabila variabel nira kelapa bertambah 1 liter maka produksi gula kelapa akan meningkat sebesar $0.054 \mathrm{~kg}$.

b) Variabel jumlah pohon berpengaruh positif terhadap produksi gula kelapa dengan koefisien regresi jumlah pohon kelapa sebesar 0.105 , artinya apabila variabel jumlah pohon kelapa bertambah 1 pohon maka produksi gula kelapa akan meningkat sebesar 0.105 $\mathrm{kg}$.

c) Variabel bahan bakar berpengaruh positif terhadap produksi gula kelapa dengan koefisien regresi bahan bakar sebesar 0.00016 ,artinya apabila variabel bahan bakar bertambah Rp. 1000 maka produksi gula kelapa akan meningkat sebesar $0.16 \mathrm{~kg}$.

d) Variabel Biaya bahan penolongberpengaruh positif 
terhadap produksi gula kelapa dengan koefisien regresi sebesar 0.00015 , artinya apabila variabelbiaya bahan penolongbertambah Rp. 1000 maka produksi gula kelapa akan meningkat sebesar 0.15 $\mathrm{kg}$.

e) Variabel umur tanamanberpengaruh positif terhadap produksi gula kelapa dengan koefisien regresi sebesar 0.159 ,artinya apabila variabelumur

tanamanbertambah 1 tahun maka produksi gula kelapa akan meningkat sebesar 0.159 $\mathrm{kg}$.

\subsection{Saran}

1. Jumlah nira yang dihasilkan tergantung jumlah pohon sehingga untuk meningkatkan kapasitas produksi petani harus menambah jumlah pohon yang disadap.

2. Perlunya permodalan dari puhak selain tengkulak agar petani tidak terikat dengan tengkulak dalam hal pemasaran hasil produksi.

\section{DAFTAR PUSTAKA}
Amin, $\quad 2009$. Cocopreneurship: Aneka Peluang Bisnis dari Kelapa. Yogyakarta.

Ardi Nugroho, Listyawan. 2011. Pengaruh Modal Usaha. Yogyakarta. Pustaka Pelajar.
Arikunto, Suharsimi. 2008. Prosedur Penelitian. Suatu Pendekatan Praktek. Jakarta. Rineka Cipta

Arikunto, Suharsimi. 1998. Prosedur Penelitian. Suatu Pendekatan Praktek. Jakarta. Rineka Cipta

Badan Pusat StatistikProvinsiRiau, 2010 Produksi kelapa di Kabupaten Indragiri Hilir Riau

Chamdi, AN. 2003. Kajian Profil Sosial Ekonomi Usaha Kambing di Kecamatan Krademan Kabupaten Grobokan. Prosiding Seminar Nasional teknologi Peternakan dan Veteriner. Bogor. 20 - 30 September 2003. Bogor. Puslitbang Peternakan Departemen Pertanian.

Daniel, Moehar. 2002. Pengantar Ekonomi Pertanian. Bumi Aksara. Jakarta.

Duwi, Priyanto. 2009. Belajar Olah Data Dengan SPSS 17. ANDI. Yogyakarta

Dyanti, 2002. Studi Komparatif Gula Merah Kelapa dan Gula Merah Aren.Skripsi. Jurusan Teknologi Pangan dan Gizi.Fakultas Teknologi Pertanian.Institut Pertanian Bogor. Bogor

Foale M. and H. Haries. 2009. Coconut. $<$ http://www.agrofore stry.net/scps $>$. Diakses pada tanggal 3 April 2013

Ghozali, Imam. 2005. Aplikasi Analisis Multivariate dengan program SPSS, Badan Penerbit 
Universitas Diponegoro,

Semarang. 